\title{
FR209602 and Related Compounds, Novel Antifungal Lipopeptides from Coleophoma crateriformis No.738
}

\author{
I. Taxonomy, Fermentation, Isolation and Physico-chemical Properties
}

\author{
Ryuichi Kanasaki, Kazutoshi Sakamoto, Michizane Hashimoto, Shigehiro Takase, \\ Yasuhisa Tsurumi, Akihiko Fujie, Motohiro Hino, Seiji Hashimoto, Yasuhiro Hori
}

Received: September 7, 2005 / Accepted: February 24, 2006

(C) Japan Antibiotics Research Association

\begin{abstract}
Novel antifungal lipopeptides, FR209602, FR209603 and FR209604, were isolated from the fermentation broth of a fungal strain No. 738 which was identified as Coleophoma crateriformis from morphological and physiological characteristics. The antibiotics were purified by solvent extraction, HP-20, YMC-ODS and silica gel column chromatography and lyophilization. These compounds were structurally similar to FR901379 previously reported by ourselves which had a sulfate residue in the cyclic peptide portion.
\end{abstract}

Keywords FR209602, FR209603, FR209604, antifungal, $1,3-\beta$-glucan synthesis

\section{Introduction}

The fungal cell wall, which is composed of glucan, chitin and mannan, is an ideal target for antifungal drugs, because it is essential to fungi and fundamentally different compared to mammalian cells. In particular, $1,3-\beta$-glucan is a promising target for antifungal agents [1]. In recent years, two new antifungal drugs, micafungin [2 4] and caspofungin [5], which inhibit fungal 1,3- $\beta$-glucan synthase, have been launched.

R. Kanasaki (Corresponding author), K. Sakamoto, M. Hashimoto, S. Takase, Y. Tsurumi, A. Fujie, M. Hino, S. Hashimoto, Y. Hori: Fermentation Research Laboratories, Fujisawa Pharmaceutical Co., Ltd., 5-2-3 Tokodai, Tsukuba, Ibaraki 300-2698, Japan.

E-mail: ryuichi.kanasaki@jp.astellas.com
In the course of searching for new fungal $1,3-\beta$-glucan synthesis inhibitors from microorganisms, the novel lipopeptides FR209602-4 were isolated from the cultured broth of Coleophoma crateriformis No. 738. These compounds have similar structures to FR901379, the points of difference being the amino acid constituents of the cyclic peptide portion of their structures. It is known that amino acid composition affects both the antifungal spectrum as well as the chemical stability of lipopeptides [6, 7]. Therefore, the attainment of diversity in the cyclic peptide nucleus by screening for new natural products is important for further research on antifungals of the echinocandin family.

In this paper, we describe the taxonomy, fermentation, isolation, physico-chemical properties and structure elucidation.

\section{Materials and Methods}

\section{General Procedures}

Melting points were taken on a Yanagimoto micro melting point apparatus. IR spectra were measured on a PerkinElmer 16PC FT-IR. UV spectra were recorded on a 220A spectrophotometer. Optical rotations were determined on a Jasco Dip-140 polarimeter, using a $10 \mathrm{~cm}$-micro cell. ${ }^{1} \mathrm{H}$ $(500 \mathrm{MHz}),{ }^{13} \mathrm{C}(125 \mathrm{MHz})$ and all 2D NMR spectra were obtained with a Bruker DRX500 spectrometer. ESI-MS and HRESI-MS spectra were measured on a Micromass-LCT.

\section{Taxonomic Studies}

The producing fungus, strain No. 738 , was originally 
isolated from a leaf sample collected at Mt. Tateyama, Toyama Prefecture, Japan. The cultural characteristics on various agar media were observed after 14 days of incubation at $25^{\circ} \mathrm{C}$ : malt extract agar, potato dextrose agar (Difco 0013), Czapek's solution agar, Sabouraud dextrose agar (Difco 0190), Emerson Yp Ss agar (Difco 0739), corn meal agar (Difco 0386), MY20 agar. The compositions of malt extract agar, Czapek's solution agar and MY20 agar were based on the JCM Catalogue of Strains [8]. The color descriptions used in this study were taken from the Methuen Handbook of Colour [9]. The temperature range of growth was determined on potato dextrose agar (NISSUI). The morphological characteristics were examined from the cultures of sterile leaf segments affixed on a Miura's LCA plate [10].

\section{Fermentation}

An aqueous seed medium $(60 \mathrm{ml})$ containing sucrose $4.0 \%$, glucose $1.0 \%$, soluble starch $2.0 \%$, Pharmamedia $3.0 \%$, soybean flour $1.5 \%, \mathrm{KH}_{2} \mathrm{PO}_{4} 1.0 \%, \mathrm{CaCO}_{3} 0.2 \%$, Adekanol LG-109 (defoaming agent, Asahi Denka Co., Ltd.) 0.05\% and Silicone KM-70 (defoaming agent, Shin-Etsu Chemical Co., Ltd.) $0.05 \%$ was placed in a $225-\mathrm{ml}$ Erlenmeyer flask and was sterilized at $120^{\circ} \mathrm{C}$ for 30 minutes. A loopful of C. crateriformis No. 738 was used to inoculate the seed flask. The inoculated flask was shaken on a rotary shaker $\left(220 \mathrm{rpm}, 5.1 \mathrm{~cm}\right.$ throw) at $25^{\circ} \mathrm{C}$ for 7 days, and $8 \mathrm{ml}$ of the seed culture was transferred to $160 \mathrm{ml}$ of the same sterile seed medium in the 500-ml Erlenmeyer flasks. The flasks were shaken on a rotary shaker $(220 \mathrm{rpm}$, $5.1 \mathrm{~cm}$ throw) at $25^{\circ} \mathrm{C}$ for 2 days, and $640 \mathrm{ml}$ (four flasks) of the second seed culture was used to inoculate 20 liters of sterile production medium consisting of modified starch
$3.0 \%$, starch acid hydrolysates $6.0 \%$, Pharmamedia $1.0 \%$, chicken meat bone meal $1.0 \%$, dried yeast $2.0 \%$, $\left(\mathrm{NH}_{4}\right)_{2} \mathrm{SO}_{4} 0.05 \%, \mathrm{Na}_{2} \mathrm{HPO}_{4} \cdot 12 \mathrm{H}_{2} \mathrm{O}, \beta$-cyclodextrin $1.0 \%$, Adekanol LG-109 0.05\% and Silicone KM-70 0.05\% in a 30 -liter jar fermentor. The fermentation was conducted at $25^{\circ} \mathrm{C}$ for 4 days under aeration of 20 liters/minute and agitation of $250 \mathrm{rpm}$.

\section{HPLC Analysis}

Detection of FR209602, FR209603 and FR209604 in the fermentation broth and fractions during purification was performed by HPLC using a reverse phase column YMC Pack ODS-AM 303, S-5 120A $(250 \times 4.6$ mm I.D., YMC Co., Ltd.). The mobile phase was $55 \%$ aqueous acetonitrile containing $0.5 \% \mathrm{NaH}_{2} \mathrm{PO}_{4} \cdot 2 \mathrm{H}_{2} \mathrm{O}$. The flow rate was $1.0 \mathrm{ml} /$ minute. The detection wavelength was set at $210 \mathrm{~nm}$.

\section{Results}

\section{Characteristics of the Producing Strain}

The cultural characteristics are summarized in Table 1. The growth of the microorganism was rather restricted on various agar media and grayish colonies were formed. Growth on potato dextrose agar was rather rapid, reaching $3 \sim 4 \mathrm{~cm}$ in diameter after two weeks at $25^{\circ} \mathrm{C}$. The colony surface was convex to raised, cottony and partly fasciate, sectoring, and showed several colors: pale gray to olive at the center; white to yellowish white at the margin; and olive brown at the sectors. The colony margin was hygroscopic and lustrous. The reverse was yellowish gray; olive gray at the sectors. Growth on corn meal agar was rather restricted, with colonies attaining $2.5 \sim 3.5 \mathrm{~cm}$ in diameter under the

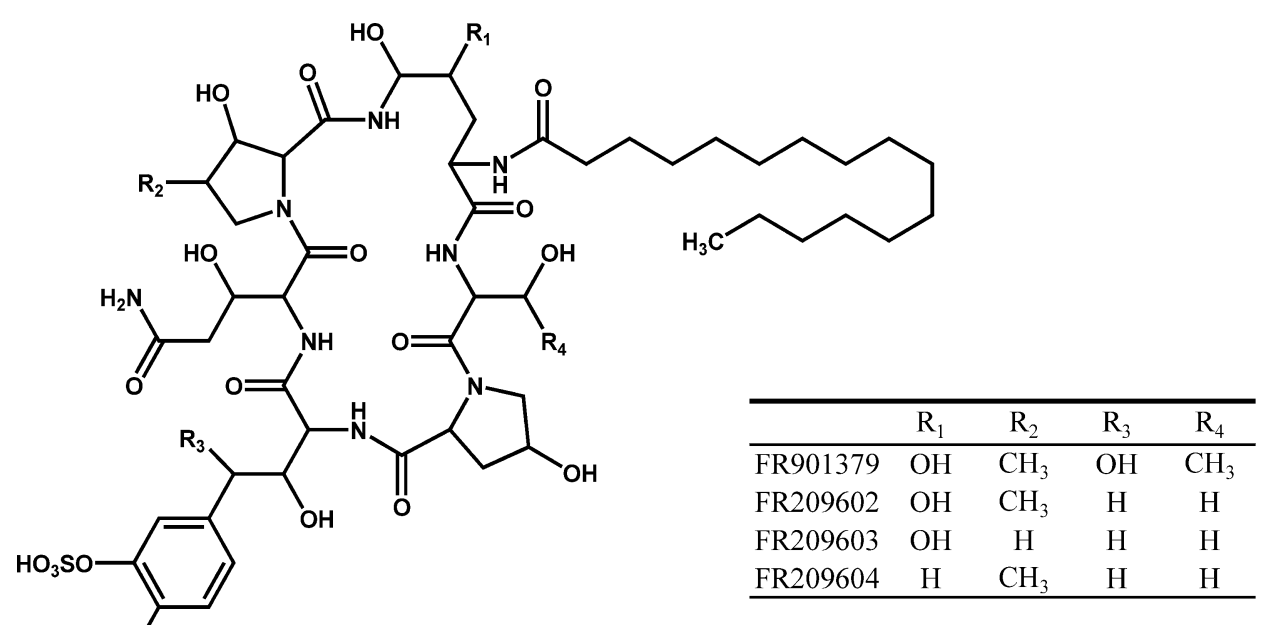

Fig. 1 Structures of FR901379, FR209602, FR209603 and FR209604. 
Table 1 Cultural characteristics of strain No. 738

\begin{tabular}{|c|c|c|}
\hline Media & & Cultural characteristics \\
\hline \multirow[t]{3}{*}{ Malt extract agar } & G: & Rather restricted, $3.0 \sim 3.5 \mathrm{~cm}$ \\
\hline & S: & $\begin{array}{l}\text { Circular, flat, velvety, exudate at the center, not formed reproductive structures, dark gray } \\
(1 \mathrm{~F} 1) \text { to violet gray (16F2) at the center and yellowish white (4A2) to yellowish gray (4B2) } \\
\text { at the margin }\end{array}$ \\
\hline & R: & Dark gray (1F1) at the center and yellowish gray (4B2) to olive gray (4D3) at the margin \\
\hline \multirow[t]{3}{*}{ Potato dextrose agar (Difco 0013) } & G: & Rather rapidly, $3.0 \sim 4.0 \mathrm{~cm}$ \\
\hline & S: & $\begin{array}{l}\text { Circular to irregular, convex to raised, cottony and partly fasciate, hygroscopic and lustrous } \\
\text { at the margin, sectoring, not formed reproductive structures, pale gray (1B1) to olive (1F3) } \\
\text { at the center, white to yellowish white (4A2) at the margin and olive brown (4F3) at the } \\
\text { sectors }\end{array}$ \\
\hline & R: & Yellowish gray (2B-C2), and olive gray (2F2) at the sectors \\
\hline \multirow[t]{3}{*}{ Czapek's solution agar } & G: & Very restricted, $0.5 \mathrm{~cm}$ \\
\hline & S: & Irregular, scanty, flat, not formed reproductive structures, grayish brown (5F3) \\
\hline & R: & Brownish gray (5F2) \\
\hline \multirow{3}{*}{ Sabouraud dextrose agar (Difco 0190) } & G: & Rather restricted, $3.0 \sim 3.5 \mathrm{~cm}$ \\
\hline & S: & $\begin{array}{l}\text { Circular, convex, velvety and partly fasciate, hygroscopic, lustrous, sectoring, not formed } \\
\text { reproductive structures, yellowish white }(4 A 2) \text {, and grayish brown (5D-E3) at the center } \\
\text { and sectors }\end{array}$ \\
\hline & R: & Pale yellow (4A3), and olive brown (4D3) at the sectors \\
\hline \multirow[t]{2}{*}{ Emerson Yp Ss agar (Difco 0739) } & G: & restricted, $1.5 \sim 2.5 \mathrm{~cm}$ \\
\hline & S: & $\begin{array}{l}\text { Circular to irregular, flat to raised, velvety, sulcate, sectoring, not formed reproductive } \\
\text { structures, pale gray (1B1) to light gray (1D1), produced dark green soluble pigment } \\
\text { Olive (1-2F3), and yellowish gray (2D2) at the center }\end{array}$ \\
\hline \multirow[t]{3}{*}{ Corn meal agar (Difco 0386) } & G: & Rather restricted, $2.5 \sim 3.5 \mathrm{~cm}$ \\
\hline & S: & $\begin{array}{l}\text { Circular, flat, velvety, submerged at the margin, lustrous, not formed reproductive } \\
\text { structures, dark gray ( } 1 \mathrm{~F} 1) \text { to olive gray }(2 \mathrm{~F} 2) \text {, and olive (1E-F4) at the margin }\end{array}$ \\
\hline & R: & Black, and olive gray (2E2) at the margin \\
\hline \multirow[t]{3}{*}{ MY20 agar } & G: & Rather restricted, $2.5 \sim 3.5 \mathrm{~cm}$ \\
\hline & S: & $\begin{array}{l}\text { Circular to irregular, flat, velvety, hygroscopic, sectoring, not formed reproductive } \\
\text { structures, olive brown (4D4-4F3), and grayish orange (6B3) at the center }\end{array}$ \\
\hline & R: & Olive brown (4E4), and pale orange (5A3) at the center \\
\hline
\end{tabular}

Abbreviations: G, growth, measuring colony size in diameter; $S$, colony surface; $R$, reverse.

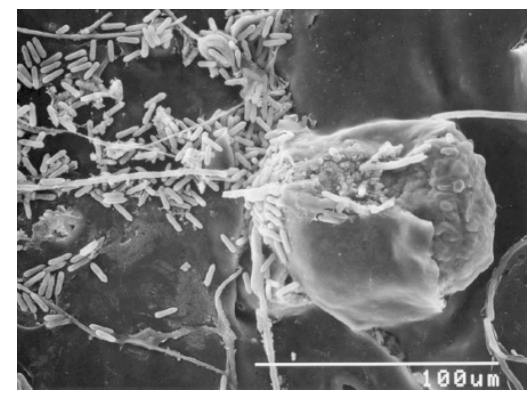

Fig. 2 Electron micrograph of strain No. 738.

same conditions. The surface was flat, velvety and dark gray to olive gray. The colony margin was subimmersed, lustrous and olive. The reverse was black; olive gray at the margin. Strain No. 738 was able to grow at a temperature range from 3 to $30^{\circ} \mathrm{C}$, with the growth optimum at $20 \sim 24^{\circ} \mathrm{C}$.

Strain No.738 produced pycnidial conidiomata in the autoclaved leaf segments affixed on LCA media (Fig. 2), while it formed neither teleomorph nor anamorph on/in agar media. The pycnidia were superficial, separate, and dark brown to black. Their shape was discoid or sometimes papillate, flattened at the base, non-ostiolate or indistinctly ostiolate, unilocular, 90 160( 400) $\mu \mathrm{m}$ in diameter and $50 \sim 90 \mu \mathrm{m}$ high. Pycnidial walls were composed of $1 \sim 2$ cells layer. Their cells were thick, but thin at the upper part, brown, and composed of textura angularis. The lower cells of inner walls were hyaline, subglobose, $4 \sim 6(\sim 7.5) \mu \mathrm{m}$ in diameter, and formed conidiophores. The conidiophores 
were hyaline, smooth, septate, simple to sparingly branched, and $3 \sim 13.5 \times 3 \sim 4 \mu \mathrm{m}$. They formed discrete conidiogenous cells at the apex. The conidiogenous cells were ampulliform to lageniform or cylindrical, and $4 \sim 8.5 \times 2.5 \sim 4 \mu \mathrm{m}$. Conidia were hyaline, smooth, amerosporous, cylindrical, rounded at the apical end, with a small projection at the base, and $10 \sim 13 \times 2 \sim 3 \mu \mathrm{m}$. Both conidia and conidiogenous cells were covered with large sheaths. The sheaths were hyaline, thin-walled campanulate to cylindrical and $14 \sim 21.5 \times 3 \sim 5 \mu \mathrm{m}$. Vegetative hyphae were smooth, septate, brown and branched. The hyphal cells were cylindrical, and $2 \sim 7 \mu \mathrm{m}$ in width. Chlamydospores were not observed.

Comparison of the morphological characteristics of strain No. 738 with fungal taxonomic criteria of von Arx [11] and Sutton [12] indicated that it resembled the coelomycete species Coleophoma crateriformis (Dur. \& Mont.) Höhn. 1907. There were a few differences between the above characteristics and Sutton's description of $C$. crateriformis: superficial, non-ostiolate or indistinctly ostiolate conidiomata, and sheaths that wrapped conidiogenous cells and conidia. The former discrepancy may be an artifact of pure culture and the sheaths were described as paraphyses by Sutton. Thus, we identified the strain as belonging to $C$. crateriformis, and named it Coleophoma crateriformis No. 738. This strain has been deposited to the International Patent Organism Depositary in the National Institute of Advanced Industrial Science and Technology, Japan, as FERM BP-5796.

\section{Isolation and Purification of FR209602, FR209603 and FR209604}

The culture broth (20 liters) was extracted with an equal volume of acetone by stirring for 1 hour at room temperature. The mixture was filtered with the aid of diatomaceous earth. The filtrate was concentrated in vacuo to remove acetone and adsorbed onto a column (1.5 liters) of DIAION HP-20 (Mitsubishi Chemical Co., Ltd.) packed with water. The column was washed with water (4.5 liters) and $50 \%$ aqueous methanol (4.5 liters), and then eluted with methanol (3 liters). The active fraction was concentrated in vacuo to an aqueous solution and an equal volume of ethyl acetate was added. The aqueous layer was passed through a column $(100 \mathrm{ml})$ of YMC-GEL (ODS-AM 120-S50, YMC Co., Ltd.) packed with water. The column was washed with $20 \%$ and $40 \%$ aqueous acetonitrile containing $0.5 \% \mathrm{NaH}_{2} \mathrm{PO}_{4} \cdot 2 \mathrm{H}_{2} \mathrm{O}(300 \mathrm{ml})$, respectively, and then eluted with $50 \%$ aqueous acetonitrile containing $0.5 \% \quad \mathrm{NaH}_{2} \mathrm{PO}_{4} \cdot 2 \mathrm{H}_{2} \mathrm{O}(200 \mathrm{ml})$. The active fraction was concentrated in vacuo to an aqueous solution and adsorbed onto a column $(20 \mathrm{ml})$ of DIAION HP-20 packed with water. The column was washed with water $(200 \mathrm{ml})$ and eluted with methanol $(60 \mathrm{ml})$. The active fraction was concentrated in vacuo to an aqueous solution and passed through a column $(175 \mathrm{ml})$ of YMC-GEL (ODS-AM 120-S50) packed with water. The column was eluted with $45 \%$ aqueous acetonitrile containing $0.5 \%$ $\mathrm{NaH}_{2} \mathrm{PO}_{4} \cdot 2 \mathrm{H}_{2} \mathrm{O}$. The active fraction was desalted using a column $(20 \mathrm{ml})$ of DIAION HP-20 and further purified by preparative HPLC, using a YMC-packed column (ODS-AM SH-343-5AM S-5, 250×20 mm i.d., YMC Co., Ltd.) with $55 \%$ aqueous acetonitrile containing $0.5 \%$ $\mathrm{NaH}_{2} \mathrm{PO}_{4} \cdot 2 \mathrm{H}_{2} \mathrm{O}$ as a mobile phase with a flow rate of $9.9 \mathrm{ml} /$ minute. Fractions containing FR209602, FR209603 and FR209604 were collected and desalted using columns $(20 \mathrm{ml})$ of DIAION HP-20, respectively. Active fractions containing the FR209602 and FR209604 substance were concentrated in vacuo and lyophilized to give $22.3 \mathrm{mg}$ of FR209602 substance and $4.2 \mathrm{mg}$ of FR209694 substance as white powders, respectively. Active fractions containing the FR209603 substance were lyophilized and dissolved in methanol $(100 \mu \mathrm{l})$, and then applied to a column $(2.5 \mathrm{ml})$ of Silica gel 60 (200 230 mesh, Merck Co., Ltd.) packed with acetone. The column was washed with acetonemethanol $(10: 1,7.5 \mathrm{ml})$ and acetone - methanol $(5: 1$, $7.5 \mathrm{ml})$, and then eluted with acetone-methanol $(3: 1$, $5 \mathrm{ml}$ ). The eluate was dried, dissolved in distilled water and lyophilized to give $1.2 \mathrm{mg}$ of FR209603 as white powder.

\section{Physico-chemical Properties}

Physico-chemical properties of FR209602, FR209603 and FR209604 are summarized in Table 2. All of them were soluble in water, methanol and dimethyl sulfoxide but insoluble in $n$-hexane and chloroform. They displayed positive color reactions to iodine vapor and ceric sulfate though they were negative against Molish, Dragendorff, and $\mathrm{FeCl}_{3}$. The ESI-MS spectra showed molecular ion peaks at $m / z 1145(\mathrm{M}+\mathrm{H})^{+}, 1131(\mathrm{M}+\mathrm{H})^{+}$and 1129 $(\mathrm{M}+\mathrm{H})^{+}$, respectively.

\section{Structure Elucidation of FR209602}

For convenience, the same numbering systems and abbreviations for rare amino acids as those used for echinocandin-like lipopeptides by researchers at Merck laboratories have been adopted. The amino acid abbreviations are shown in Table 3.

The molecular formula $\mathrm{C}_{50} \mathrm{H}_{80} \mathrm{~N}_{8} \mathrm{O}_{20} \mathrm{~S}$ was determined by HR-ESIMS and the elemental analysis (Table 2). At first, the structure of FR209602 was elucidated by comparison of the ${ }^{1} \mathrm{H}$ and ${ }^{13} \mathrm{C}$ NMR data with those of FR901379 $[13,14]$ and it was finally established by application of a series of 2-D NMR techniques. In the ${ }^{1} \mathrm{H}$ NMR spectrum of 
Table 2 Physico-chemical properties of FR209602, FR209603 and FR209604

\begin{tabular}{|c|c|c|c|}
\hline & FR209602 & FR209603 & FR209604 \\
\hline Appearance & White powder & White powder & White powder \\
\hline Melting point & $173 \sim 177^{\circ} \mathrm{C}$ & $160 \sim 164^{\circ} \mathrm{C}$ & $155 \sim 160^{\circ} \mathrm{C}$ \\
\hline$[\alpha]_{D}^{23}$ & $-10^{\circ}$ (c $\left.0.5, \mathrm{MeOH}\right)$ & $-7.6^{\circ}(c 0.5, \mathrm{MeOH})$ & $-2^{\circ}(c 0.35, \mathrm{MeOH})$ \\
\hline ESI-MS $(m / z)$ & $1145(\mathrm{M}+\mathrm{H})^{+}$ & $1131(\mathrm{M}+\mathrm{H})^{+}$ & $1129(\mathrm{M}+\mathrm{H})^{+}$ \\
\hline \multicolumn{4}{|l|}{ HRESI-MS $(\mathrm{m} / \mathrm{z})$} \\
\hline Found & 1145.5287 & 1131.5128 & 1129.5331 \\
\hline Calcd for $\mathrm{M}+\mathrm{H}$ & 1145.5288 & 1131.5131 & 1129.5338 \\
\hline Molecular formula & $\mathrm{C}_{50} \mathrm{H}_{80} \mathrm{~N}_{8} \mathrm{O}_{20} \mathrm{~S}$ & $\mathrm{C}_{49} \mathrm{H}_{78} \mathrm{~N}_{8} \mathrm{O}_{20} \mathrm{~S}$ & $\mathrm{C}_{50} \mathrm{H}_{80} \mathrm{~N}_{8} \mathrm{O}_{19} \mathrm{~S}$ \\
\hline \multicolumn{4}{|l|}{ Elemental analysis } \\
\hline Calcd as hexahydrate & C 47.09, H 7.19, N 8.79, S 2.51 & Not determined & Not determined \\
\hline Found: & C 47.23, H 7.35, N 8.56, S 2.18 & Not determined & Not determined \\
\hline$U V \lambda_{\max }^{\mathrm{MeOH}} \mathrm{nm}(\varepsilon)$ & $278(1500)$ & $275(1900)$ & $277(1600)$ \\
\hline \multicolumn{4}{|l|}{ Color test } \\
\hline Positive & $\mathrm{I}_{2}, \mathrm{Ce}\left(\mathrm{SO}_{4}\right)_{2}-\mathrm{H}_{2} \mathrm{SO}_{4}$ & $\mathrm{I}_{2}, \mathrm{Ce}\left(\mathrm{SO}_{4}\right)_{2}-\mathrm{H}_{2} \mathrm{SO}_{4}$ & $\mathrm{I}_{2}, \mathrm{Ce}\left(\mathrm{SO}_{4}\right)_{2}-\mathrm{H}_{2} \mathrm{SO}_{4}$ \\
\hline Negative & Molish, Dragendorff, $\mathrm{FeCl}_{3}$ & Molish, Dragendorff, $\mathrm{FeCl}_{3}$ & Molish, Dragendorff, $\mathrm{FeCl}_{3}$ \\
\hline \multicolumn{4}{|l|}{ Solubility } \\
\hline Soluble & $\mathrm{H}_{2} \mathrm{O}$, methanol, DMSO & $\mathrm{H}_{2} \mathrm{O}$, methanol, DMSO & $\mathrm{H}_{2} \mathrm{O}$, methanol, DMSO \\
\hline Insoluble & $n$-hexane, chloroform & n-hexane, chloroform & n-hexane, chloroform \\
\hline $\mathrm{IR} \lambda_{\max }(\mathrm{KBr}) \mathrm{cm}^{-1}$ & $\begin{array}{l}3350,2930,2850,1650,1640 \\
1520,1460,1270,1250,1050\end{array}$ & $\begin{array}{l}3360,2930,2850,1650,1630,1540 \\
1520,1440,1280,1250,1050\end{array}$ & $\begin{array}{l}3350,2920,2850,1650,1640 \\
1540,1520,1450,1270,1050\end{array}$ \\
\hline TLC (Rf value)* & 0.42 & 0.34 & 0.40 \\
\hline
\end{tabular}

* Silica gel $60 \mathrm{~F}_{254}$ (E. Merck Co.): $n$-BuOH -acetic acid- $\mathrm{H}_{2} \mathrm{O}(4: 1: 2)$.

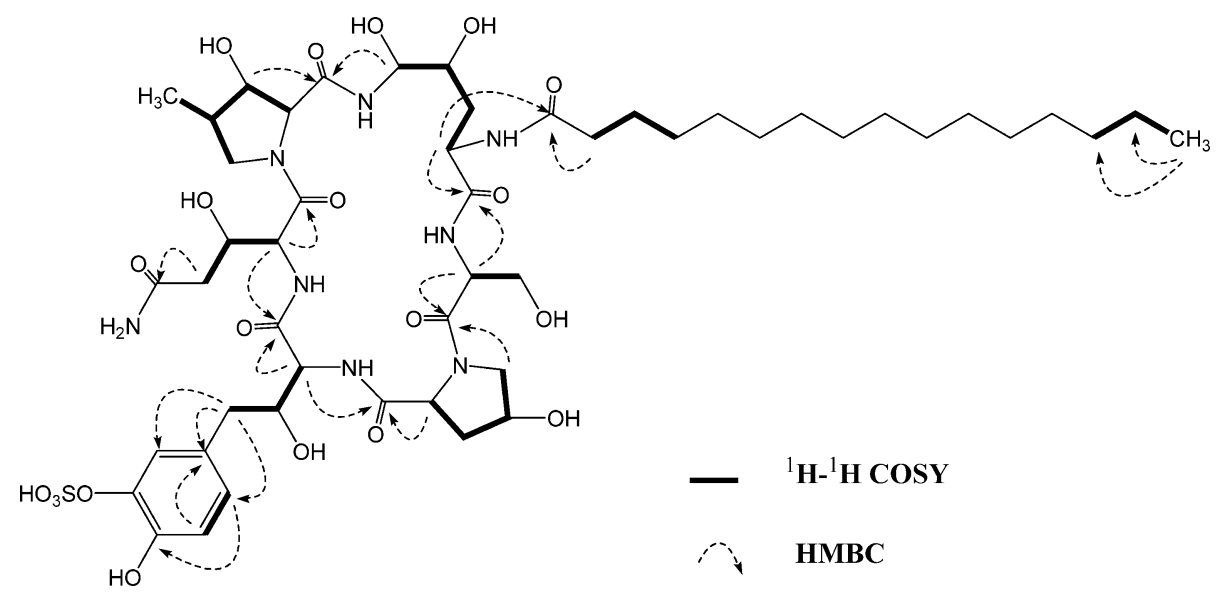

Fig. $3{ }^{1} \mathrm{H}-{ }^{1} \mathrm{H}$ COSY and key HMBC correlations of FR209602.

FR901379, two secondary methyl signals were particularly diagnostic: a doublet methyl signal resonating at $1.18 \mathrm{ppm}$ was characteristic for the Thr methyl and a doublet at $1.05 \mathrm{ppm}$ for the 4-methyl of 3-hydroxy-4-methylproline (OHMePro; see FR209603 below). The absence of a 1.18 ppm doublet in the ${ }^{1} \mathrm{H}$ spectrum of FR209602 implied the lack of a Thr residue. By a combined analysis of ${ }^{1} \mathrm{H}-{ }^{1} \mathrm{H}$
COSY and HSQC, the following spin units were deduced. The presence of Ser was inferred from the spin system (methylene $\left(\delta_{\mathrm{H}} 4.23,3.73 / \delta_{\mathrm{C}} 63.6\right)$ and methine $\left(\delta_{\mathrm{H}}\right.$ $\left.\left.4.91 / \delta_{\mathrm{C}} 56.0\right)\right)$. Meta-coupled benzene protons $\left(\delta_{\mathrm{H}} 7.16\right.$ and 6.88) showed long-range ${ }^{1} \mathrm{H}-{ }^{1} \mathrm{H}$ correlations to methylene $\left(\delta_{\mathrm{H}} 2.58 / \delta_{\mathrm{C}} 40.7\right)$. These key observations indicated the replacement of Thr by Ser and deoxygenation at C-4 in the 
142

Table $3{ }^{13} \mathrm{C}$ NMR data for FR209602, FR209603, FR209604 and FR901379 (125 MHz, CD ${ }_{3}$ OD)

\begin{tabular}{|c|c|c|c|c|}
\hline Position & FR209602 & FR209603 & FR209604 & FR901379 \\
\hline \multicolumn{5}{|c|}{ 4,5-Dihydroxyornithine (DiOHOrn) } \\
\hline C-1 & $173.8 \mathrm{~s}$ & $173.8 \mathrm{~s}$ & $174.5 \mathrm{~s}$ & $174.4 \mathrm{~s}$ \\
\hline $\mathrm{C}-2$ & $51.3 d$ & $51.2 \mathrm{~d}$ & $52.0 d$ & $51.5 d$ \\
\hline $\mathrm{C}-3$ & $35.9 t$ & $35.5 t$ & $27.3 t$ & $35.0 \mathrm{t}$ \\
\hline C-4 & $70.7 d$ & $70.7 d$ & $30.9 \mathrm{t}$ & $70.7 d$ \\
\hline$C-5$ & $74.3 d$ & $74.2 d$ & $71.9 d$ & $74.4 \mathrm{~d}$ \\
\hline \multicolumn{5}{|c|}{ Serine (Ser) } \\
\hline C-1 & $171.9 \mathrm{~s}$ & $172.0 \mathrm{~s}$ & $171.8 \mathrm{~s}$ & $172.6 \mathrm{~s}$ \\
\hline $\mathrm{C}-2$ & $56.0 d$ & $56.0 \mathrm{~d}$ & $56.0 d$ & $58.4 d$ \\
\hline $\mathrm{C}-3$ & $63.6 \mathrm{t}$ & $63.6 \mathrm{t}$ & $63.8 \mathrm{t}$ & $68.2 d$ \\
\hline C-4 & & & & $19.8 \mathrm{q}$ \\
\hline \multicolumn{5}{|c|}{ 4-Hydroxyproline (OHPro) } \\
\hline C-1 & $174.1 \mathrm{~s}$ & $174.2 \mathrm{~s}$ & $174.1 \mathrm{~s}$ & $173.5 \mathrm{~s}$ \\
\hline $\mathrm{C}-2$ & $62.3 d$ & $62.4 \mathrm{~d}$ & $62.5 \mathrm{~d}$ & $62.4 \mathrm{~d}$ \\
\hline $\mathrm{C}-3$ & $39.0 \mathrm{t}$ & $39.0 \mathrm{t}$ & $39.0 t$ & $38.4 \mathrm{t}$ \\
\hline C-4 & $71.2 \mathrm{~d}$ & $71.3 d$ & $71.3 d$ & $71.3 d$ \\
\hline C-5 & $57.0 \mathrm{t}$ & $57.0 \mathrm{t}$ & $57.0 \mathrm{t}$ & $57.1 \mathrm{t}$ \\
\hline \multicolumn{5}{|c|}{ 3,4-Dihydroxyhomotyrosine (DiOHTyr) } \\
\hline $\mathrm{C}-1$ & $172.5 \mathrm{~s}$ & $172.7 \mathrm{~s}$ & $172.8 \mathrm{~s}$ & $172.5 \mathrm{~s}$ \\
\hline $\mathrm{C}-2$ & $58.4 d$ & $58.3 d$ & $58.2 d$ & $57.1 \mathrm{~d}$ \\
\hline $\mathrm{C}-3$ & $73.7 \mathrm{~d}$ & $73.8 d$ & $73.9 d$ & $76.3 d$ \\
\hline C-4 & $40.7 \mathrm{t}$ & $40.8 \mathrm{t}$ & $40.8 \mathrm{t}$ & $75.5 d$ \\
\hline $\mathrm{C}-1^{\prime}$ & $130.9 \mathrm{~s}$ & $131.0 \mathrm{~s}$ & $131.1 \mathrm{~s}$ & $134.6 \mathrm{~s}$ \\
\hline C-2' & $125.1 d$ & $125.3 d$ & $125.3 d$ & $123.2 \mathrm{~d}$ \\
\hline C-3' & $141.0 \mathrm{~s}$ & $141.1 \mathrm{~s}$ & $141.1 \mathrm{~s}$ & $141.1 \mathrm{~s}$ \\
\hline C-4' & $149.1 \mathrm{~s}$ & $149.1 \mathrm{~s}$ & $149.1 \mathrm{~s}$ & $150.3 \mathrm{~s}$ \\
\hline$C-5^{\prime}$ & $118.2 \mathrm{~d}$ & $118.2 \mathrm{~d}$ & $118.2 d$ & $118.3 d$ \\
\hline C-6 $6^{\prime}$ & $127.9 d$ & $128.0 \mathrm{~d}$ & $128.0 \mathrm{~d}$ & $125.5 d$ \\
\hline \multicolumn{5}{|c|}{ 3-Hydroxyglutamine (OHGIn) } \\
\hline $\mathrm{C}-1$ & $169.4 \mathrm{~s}$ & $169.5 \mathrm{~s}$ & $169.1 \mathrm{~s}$ & $169.4 \mathrm{~s}$ \\
\hline $\mathrm{C}-2$ & $55.4 d$ & $55.4 d$ & $55.4 d$ & $55.5 d$ \\
\hline $\mathrm{C}-3$ & $70.6 d$ & $70.6 d$ & $70.6 d$ & $70.7 d$ \\
\hline C-4 & $39.6 \mathrm{t}$ & $39.5 \mathrm{t}$ & $39.5 \mathrm{t}$ & $39.7 \mathrm{t}$ \\
\hline C-5 & $176.7 \mathrm{~s}$ & $176.7 \mathrm{~s}$ & $176.9 \mathrm{~s}$ & $176.8 \mathrm{~s}$ \\
\hline \multicolumn{5}{|c|}{ 3-Hydroxy-4-methylproline (OHMePro) } \\
\hline $\mathrm{C}-1$ & $172.4 \mathrm{~s}$ & $172.6 \mathrm{~s}$ & $172.5 \mathrm{~s}$ & $172.7 \mathrm{~s}$ \\
\hline $\mathrm{C}-2$ & $70.1 \mathrm{~d}$ & $69.7 d$ & $70.3 d$ & $70.1 \mathrm{~d}$ \\
\hline $\mathrm{C}-3$ & $75.6 \mathrm{~d}$ & $73.9 \mathrm{~d}$ & $76.0 \mathrm{~d}$ & $75.7 d$ \\
\hline C-4 & $39.0 \mathrm{~d}$ & $34.6 \mathrm{t}$ & $39.1 d$ & $39.1 \mathrm{~d}$ \\
\hline C-5 & $52.8 \mathrm{t}$ & $46.9 \mathrm{t}$ & $52.9 \mathrm{t}$ & $53.0 \mathrm{t}$ \\
\hline 4-Me & $11.0 \mathrm{q}$ & & $11.1 \mathrm{q}$ & $11.1 \mathrm{q}$ \\
\hline \multicolumn{5}{|l|}{ Palmitoyl } \\
\hline C-1 & $176.1 \mathrm{~s}$ & $176.2 \mathrm{~s}$ & $176.3 \mathrm{~s}$ & $175.8 \mathrm{~s}$ \\
\hline $\mathrm{C}-2$ & $36.7 \mathrm{t}$ & $36.8 \mathrm{t}$ & $36.8 \mathrm{t}$ & $36.7 \mathrm{t}$ \\
\hline $\mathrm{C}-3$ & $26.7 t$ & $26.9 \mathrm{t}$ & $27.0 \mathrm{t}$ & $26.9 \mathrm{t}$ \\
\hline$C-4$ & $30.3 t$ & $30.3 t$ & $30.3 t$ & $30.3 t$ \\
\hline$C-5$ & $30.4 \mathrm{t}$ & $30.4 \mathrm{t}$ & $30.4 \mathrm{t}$ & $30.4 \mathrm{t}$ \\
\hline C-6 & $30.5 t$ & $30.5 t$ & $30.5 t$ & $30.5 t$ \\
\hline$C-7$ & $30.7 t$ & $30.7 t$ & $30.7 t$ & $30.7 t$ \\
\hline C-8 & $30.8 \mathrm{t}$ & $30.8 \mathrm{t}$ & $30.8 \mathrm{t}$ & $30.8 \mathrm{t}$ \\
\hline C-9 & $30.8 \mathrm{t}$ & $30.8 t$ & $30.8 \mathrm{t}$ & $30.8 \mathrm{t}$ \\
\hline C-10 & $30.8 \mathrm{t}$ & $30.8 t$ & $30.8 \mathrm{t}$ & $30.8 \mathrm{t}$ \\
\hline$C-11$ & $30.8 t$ & $30.8 \mathrm{t}$ & $30.8 t$ & $30.8 t$ \\
\hline$C-12$ & $30.8 t$ & $30.8 \mathrm{t}$ & $30.8 t$ & $30.8 t$ \\
\hline$C-13$ & $30.6 \mathrm{t}$ & $30.6 \mathrm{t}$ & $30.6 \mathrm{t}$ & $30.7 t$ \\
\hline C-14 & $32.9 \mathrm{t}$ & $33.1 \mathrm{t}$ & $33.0 \mathrm{t}$ & $33.1 \mathrm{t}$ \\
\hline C-15 & $23.6 \mathrm{t}$ & $23.7 \mathrm{t}$ & $23.7 \mathrm{t}$ & $23.7 \mathrm{t}$ \\
\hline$C-16$ & $14.4 \mathrm{q}$ & $14.4 \mathrm{q}$ & $14.4 \mathrm{q}$ & $14.4 \mathrm{q}$ \\
\hline
\end{tabular}


3,4-dihydroxyhomotyrosine residue. A combined analysis of ${ }^{1} \mathrm{H}-{ }^{1} \mathrm{H}$ COSY, HSQC and HMBC confirmed the structure as shown in Fig. 3. The ${ }^{13} \mathrm{C}$ NMR data are presented in Table 3.

\section{Structure Elucidation of FR209603}

HR-ESIMS revealed the molecular formula $\mathrm{C}_{49} \mathrm{H}_{78} \mathrm{~N}_{8} \mathrm{O}_{20} \mathrm{~S}$ $\left(\mathrm{CH}_{2}\right.$ less than FR209602). The absence of a doublet methyl signal at $1.05 \mathrm{ppm}$ indicated the lack of methyl of the OHMePro residue. This finding was consistent with the molecular formula difference between FR209602 and FR209603. A careful ${ }^{13} \mathrm{C}$ NMR comparison with FR209602 revealed the replacement of methine carbon $(39.0 \mathrm{ppm})$ in FR209602 with methylene $(34.6 \mathrm{ppm})$ in FR209603. This modification was corroborated by the upfield shift of the C-5 methylene (46.9 ppm) in FR209603 from C-5 of OHMePro (52.8 ppm) in FR209602. The ${ }^{13} \mathrm{C}$ NMR data are presented in Table 3.

\section{Structure Elucidation of FR209604}

HR-ESIMS defined the molecular formula $\mathrm{C}_{50} \mathrm{H}_{80} \mathrm{~N}_{8} \mathrm{O}_{19} \mathrm{~S}$ (one oxygen atom less than FR209602). The pattern of the hemiaminal proton signal $\left(\delta_{\mathrm{H}} 5.38 / \delta_{\mathrm{C}} 71.9\right)$ was changed from doublet $(J=3 \mathrm{~Hz})$ in FR209602 to a doublet of doublets $(J=10.5$ and $3.5 \mathrm{~Hz})$, indicating the presence of methylene at C-4 in the 4,5-dihydroxyornithine (DiOHOrn) residue. With the aid of a combined analysis of ${ }^{1} \mathrm{H}-{ }^{1} \mathrm{H}$ COSY and HSQC, a ${ }^{13} \mathrm{C}$ NMR data comparison with FR209602 revealed that the methine $(70.7 \mathrm{ppm})$ was substituted with a methylene $(30.9 \mathrm{ppm})$. With the structure, [5-hydroxyornitine]FR209602, in hand, full ${ }^{1} \mathrm{H}$ and ${ }^{13} \mathrm{C}$ NMR assignments were accomplished by extensive 2D NMR analyses $\left({ }^{1} \mathrm{H}-{ }^{1} \mathrm{H}\right.$ COSY, HSQC and HMBC). The results were in complete agreement with the structure. The ${ }^{13} \mathrm{C}$ NMR data are presented in Table 3.

\section{Discussion}

In this paper, we have presented three novel antifungal lipopeptides, FR209602, FR209603 and FR209604, isolated from the fermentation broth of $C$. crateriformis No. 738. These compounds belong to the echinocandin family, a class of antifungal agents that act on the fungal cell wall by inhibiting glucan synthesis. The members of the echinocandin family of fungal origin are FR901379 [14, 15], echinocandin B [16], aclueacins [17], mulundocandin [18] and pneumocandins [19], which are produced by $C$. empetri No. 11899, Aspergillus nidulans, A. aculeatus, A. sydowi and Glarea lozoyensis, respectively. Among these, FR901379 has good water-solubility because it has a sulfate moiety. Though FR209602, FR209603 and FR209604 also have a sulfate moiety, the amino acid constitutions of these compounds differ from those of FR901379. The acyl side chain is readily replaced by semisynthesis as we [2, 20] and others [21] acheived. However, modification of the cyclic peptide portion by chemical synthesis is not easy. The attainment of diversity in the cyclic peptide nucleus by screening for new natural products is important for further research on antifungals of the echinocandin family. Studies of the in vitro and in vivo antifungal activities of FR209602, FR209603 and FR209604 will be reported in the following paper [22].

Acknowledgment We wish to thank Mrs. Reiko Ohtsu for assistance throughout this work.

\section{References}

1. Liu J, Balasubramanian MK. 1,3-beta-Glucan synthase: a useful target for antifungal drugs. Curr Drug Targets Infect Disord 1: 159-169 (2001)

2. Tomishima M, Ohki H, Yamada A, Takasugi H, Maki K, Tawara S, Tanaka H. FK463, a novel water-soluble echinocandin lipopeptide: synthesis and antifungal activity. J Antibiot 52: 674-676 (1999)

3. Higashiyama Y, Kohno S. Micafungin: a therapeutic review. Expert Rev Anti Infect Ther 2: 345-355 (2004)

4. Jarvis B, Figgitt DP, Scott LJ. Micafungin. Drugs 64: 969-984 (2004)

5. Cornely OA, Schmitz K, Aisenbrey S. The first echinocandin: caspofungin. Mycoses 45: 56-60 (2002)

6. Lal B, Gund VG, Gangopadhyay AK, Nadkarni SR, Dikshit V, Chatterjee DK, Shirvaikar R. Semisynthetic modifications of hemiaminal function at ornithine unit of mulundocandin, towards chemical stability and antifungal activity. Bioorg Med Chem 11: 5189-5198 (2003)

7. Fromtling RA, Abruzzo GK. L-671,329, a new antifungal agent. III. In vitro activity, toxicity and efficacy in comparison to aculeacin. J Antibiot 42: 174-178 (1989)

8. Nakase T. JCM Catalogue of Strains, 6th edition. Japan Collection of Microorganisms, the Institute of Physical and Chemical Research (RIKEN), Toppan (1995)

9. Kornerup A, Wanscher JH. Methuen Handbook of Colour, 3rd edition. Methuen, London (1978)

10. Miura K, Kudo M. An agar-medium for aquatic Hyphomycetes. Trans Mycol Soc Japan 11: 116-118 (1970)

11. von ARX JA. The Genera of Fungi - Sporulating in Pure Culture, 3rd ed., J Cramer, Vaduz (1974)

12. Sutton BC. The Coelomycetes - Fungi Imperfecti with Pycnidia, Acervuli and Stroma. p. 696, Commonwealth Mycological Institute, Kew (1980)

13. Iwamoto T, Fujie A, Nitta K, Tsurumi Y, Shigematsu N, Kasahara C, Hino M, Okuhara M. (Fujisawa Pharmaceutical 
Co. Ltd.), New polypeptide compound and a process for preparation thereof. E.P. 0,431,350, Nov. 10 (1990)

14. Iwamoto T, Fujie A, Sakamoto K, Tsurumi Y, Shigematsu N, Yamashita M, Hashimoto S, Okuhara M, Kohsaka M. WF11899A, B, and C, novel antifungal lipopeptides. I. Taxonomy, fermentation, isolation and physico-chemical properties. J Antibiot 47: 1084-1091 (1994)

15. Iwamoto T, Fujie A, Nitta K, Hashimoto S, Okuhara M, Kohsaka M. WF11899A, B, and C, novel antifungal lipopeptides. II. Biological properties. J Antibiot 47: 1092-1097 (1994)

16. Nyfeler R, Keller-Schierlein W. Echinocandin B, A novel polypeptide-antibiotic from Aspergillus nidulans var. echinulatus: isolation and structural components. Helv Chim Acta 57: 2459-2477 (1974)

17 Mizuno K, Yagi A, Satoi S, Takada M, Hayashi M, Asano K, Matsuda T. Studies on aculeacin. I. Isolation and characterization of aculeacin A. J Antibiot 30: 297-302 (1977)

18 Roy K, Mukhopadhyay T, Reddy GC, Desikan KR, Ganguli BN. Mulundocandin, a new lipopeptide antibiotic. I. Taxonomy, fermentation, isolation and characterization. J
Antibiot 40: 275-280 (1987)

19. Schwartz RE, Sesin DF, Joshua H, Wilson KE, Kempf AJ, Goklen KA, Kuehner D, Gailliot P, Gleason C, White R, Inamine E, Bills G, Salmon P, Zitano L. Pneumocandins from Zalerion arboricola. I. Discovery and isolation. J Antibiot 45: 1853-1866 (1992)

20. Ueda S, Tanaka M, Ezaki M, Sakamoto K, Hashimoto S, Ito K, Nagao K, Higaki T, Oohata N, Tsuboi M, Yamashita M. Studies on a novel lipopeptide acylase (FR901379 Acylase) from Streptomyces sp. for production of FR179462, a key intermediate of antifungal lipopeptide drug FK463. Program and Abstracts of the 38th Intersci Conf on Antimicrob Agents Chemother, F-145, p. 269, San Diego, 24-27 Sept., 1998

21. Boeck LD, Fukuda DS, Abbott BJ, Debono M. Deacylation of echinocandin B by Actinoplanes utahensis. J Antibiot 42: 382-388 (1989)

22. Kanasaki R, Abe F, Furukawa S, Yoshikawa K, Fujie A, Hino M, Hashimoto S, Hori Y. FR209602 and related compounds, novel antifungal lipopeptides from Coleophoma crateriformis No. 738. II. In vitro and in vivo antifungal activity. J Antibiot 59: 145-148 (2006) 